\title{
Family Collection
}

National Cancer Institute

\section{Source}

National Cancer Institute. Family Collection. NCI Thesaurus. Code C79273.

A collection of things sharing a common attribute. 